\title{
The integrative role of planning in differentiated organizations ${ }^{1}$
}

\author{
T.L. Woodburn \\ Grey Mann Associates (Pty) Ltd, Johannesburg
}

\begin{abstract}
Using a five-cluster analysis it is found that organizations tend to require different internal structural characteristics which may be portrayed along a continuum. This represents young. small, simple organizations at the one end and older, large, complex organizations, at the other end of the continuum. As the size and complexity of organizations increase, their characteristics change so as to meet their more complex differentiative or integrative needs. In addition to changing the characteristics of the internal decision structure along the continuum to achieve integration, it is found that organizations also increase their involvement in planning as their size and complexity increase. With the aid of an environmental cluster analysis it is also observed that organizations which operate in in. creasingly complex operational environments tend to increase their degree of involvernent in corporate planning.

It is possible to conclude with confidence that the greater the differentiation and environmental uncertainty caused by growth, diversification and organizational complexity, the greater become the integrative needs provided by the range of facilities of corporate planning. The survey results reveal a facet previously ignored in the classic concept of corporate planning. While environmental uncertainty does play a part in determining the degree of an organization's involvement in the corporate planning process, the complexity of the organization itself plays a stronger and more dominant role in dictating the degree of involvement. In the South African context, planning is primarily a powerfut internal in tegrator of complex organizations, and only secondarily, a management technique for coping with uncertain future business environments. S. Afr. J. Bus. Mgmt. 1983, 14: 140- 155
\end{abstract}

Deur van 'n vyfbondelontieding gebruik te maak, is daar bevind dat organisasies neig om verskillende strukluureienskappe te vereis wat op in kontinuum weergegee kan word. Dit verteenwoordig jong, klein, een. voudige organisasies aan die een end en over, groot, komplekse organisasies aan die ander end van die kontinuum. Namate die grootte en kompleksiteit van organisasies toeneem, verander hul eienskappe om in hul meer komplekse differensierende of integrerende behoeftes te voorsien. Benewens die verandering van die eienskappe van die interne besluitstruktuur op die kontinuum om integrasie te bereik, word daar gevind dat organisasies ook hul betrokkenheid by beplanning vergroot namate hul grootte en kompleksiteit toeneem. Met behulp van 'n omgewingsbondelontleding word daar ook waargeneem dat organisasies wat in al hoe meer komplekse operasionele omgewings werksaam is, neig om hul mate van betrokkenheid in korporatiewe beplanning te vergroot.

Dit is moontlik orn met vertroue tot die gevolgtrekking te kom dat hoe groter die differensiasie en omgewingsonsekerheid is wat deur groei, diversifikasie en organisatoriese kompleksiteit veroorsaak word, hoe groter word die integrerende behoeftes wat deur die reeks fasiliteite van kor. poratiewe beplanning voorsien word. Die resultate van die opname toon 'n faset wat voorheen in die klassieke konsep van korporatiewe beplanning oor die hoof gesien is. Hoewel omgewingsonsekerheid wel 'n rol by die bepaling van die mate van 'n organisasie se betrokkenheid by die korporatiewe beplanningsproses speel, speel die kompleksiteit van die organisasie self 'n sterker en meer dominante rol by die dikteer van die mate van betrokkenheid. In die Suid-Afrikaanse konteks is beplanning primer ' $n$ magtige interne integreerder van komplekse organisasies en slegs sekonder 'n bestuurstegniek om onsekere toekomstige sakeomge wings die hoof te bied.

S.-Afr. Tydskr. Bedryfst. 1983. 14: 140-155

Dr T.L. Woodburm

Managing Director, Grey Mann Associates (Pty) Ltd,

P.O. Box 11553, Johannesburg 2000, Republic of South Africa

\section{Scope and theoretical framework}

This article examines the integrative role of planning in the light of survey results obtained from an in-depth examination of those organizational and environmental characteristics which influence the extent and nature of the corporate planning process. In order to develop implicit hypotheses in the defined area, it will be necessary first to examine some of the basic underlying theories of organizations, environments and planning.

\section{Contingency theory of organizations}

During the last decade new concepts and ideas have emerged in the study of organizations. Recent research suggests that there is no one best way or universal approach to organize an enterprise as was previously thought. It suggests that an organization is not an independent entity, but an interdependent system. This results from the complex interaction between the organization itself and its environment. The organizational form most suited to a particular setting is dependent on its internal and external environments.

Reseach exercises have indicated that effectively-functioning organizations have structural characteristics which are in harmony with the characteristics of their operational environments. It was found that a formal 'mechanistic' structure was associated with high effectiveness in stable, known environments. In contrast, a relatively informal 'organic' structure was associated with high effectiveness in dynamic unknown environments in which it was extremely difficult to anticipate the multiplicity of demands to which the organization would have to respond. While these concepts expounded by Lawrence and Lorsch ${ }^{2}$, embrace the organic/mechanistic distinction, they also assert that certain organizations can be organic and mechanistic at the same time. They also suggest that those organizations which faced diverse environments had differentiated departments and faced problems of integration.

These findings led to the conclusion that the most effective organizational form is contingent upon the nature of the environment in which the organization operates. Organizational designs appropriate to one technological and market environment are not necessarily appropriate for any other. In most cases it is necessary to tailor-make each organization and its constituent systems. This discussion of the contingency theory leads logically to a consideration of the characteristics of various environments.

\section{Environmental theories}

The concept of the environment with its components and 
dimensions does not appear to have been well specified in the literature. ${ }^{3,4}$ Lawrence and Lorch ${ }^{5}$, for example, studied how organizations segment their environments into related sectors but did not clearly conceptualize the environment. Other concepts of the task environment focused only on those parts of the organization's external environment which were associated with goal setting and attainment thereof.

In their paper on 'The Causal Texture of Organizational Environments', Emery and Trist ${ }^{6}$ suggest that the organizational cnvironments differ in their causal texture as regards degree of uncertainty. They suggest an approach which identifies the following four 'ideal types': these types are approximations which exist simultaneously in the 'real world' of most organizations, but in vastly differing combinations:

(a) placid, randomized environment;

(b) placid, clustered environment;

(c) disturbed-reactive environment;

(d) turbulent field environment.

From the Emery and Trist ${ }^{7}$ categorizations discussed above, the following two environmental dimensions can be inferred: (i) the simple-complex dimension; and

(ii) the static-dynamic dimension.

Expanding along these lines, Thompson ${ }^{8}$ shows environmental complexity as a two dimensional construct. One dimension is the relative stability of the environment, and the other the relative homogeneity. The end points of these two continua delimit four types of environmental complexity. Associated with each of the cells are the following implications (empirical evidence is still lacking) of degrees of relative uncertainty:

- Cell I: Homo-stable: The organization whose task environment is relatively homogeneous and relatively stable would be expected to be relatively simple in the structure of its boundary-spanning components. Such an organization would not be divisionalized and if these were subdivided, they would be into similar departments or sections. This organization can be expected to rely primarily on standardized responses or rules for adaptation. Its departments would be rule applying agencies, and its administration would consist of rule enforcement.

- Cell II: Homo-dynamic: If the task environment is dynamic but relatively homogeneous, the boundary-spanning component needs to be differentiated or subdivided only to the extent that its capacity to monitor the environment would be over extended. Since the environment is otherwise homogeneous, sections or departments of this organization would be expected to be established by geographical area. Regional divisions will be less concerned with the application of rules and more concerned with the planning or responses to environmental changes. In general, when the task environment is dynamic, the regional divisions will be decentralized.

- Cell III: Hetero-stable: For an organization facing a heterogeneous but stable task environment, a variety of functional and product/market divisions would be expected. Each division would correspond to a relatively homogeneous segment of the task environment, and each would rely primarily on rules to achieve adaptation. The divisions may further subdivide as rule applying agencies on a geographical basis.

- Cell IV: Hetero-dynamic: When the task environment is both heterogeneous and dynamic, the boundary-spanning units would be expected to be differentiated functionally to correspond to segments of the task environment. Each of these would operate on a decentralized basis to monitor and plan responses to fluctuations in its sector of the task environment.

The above Thompson' categorizations may be summarized as follows. The more heterogeneous the task environment, the greater the constraints presented to the organization. The more dynamic the task environment, the greater the contingencies presented to the organization. Under either of these conditions a rational organization establishes boundaries around the amount and scope of adaptation required. This is achieved by establishing structural units specialized to face a limited range of contingencies within the constraints. The greater the contingencies and constraints faced by the organization, the more its boundary-spanning component will be segmented. These conclusions of Thompson appear to be consistent with those of March and Simon ${ }^{10}$ : they predicted that process specialization would be carried furthest in stable environments and that under rapid change, specialization would be sacrificed for greater self-containment of separate programmes.

Duncan " conceptualizes the environment as the totality of physical and social factors that are taken directly into consideration, in the behaviour of the organization's decisionmaking individuals. Using Duncan's ${ }^{12}$ definition of the environment, there are then factors within the boundaries of the organization or units of the organization that must be considered an integral part of the environment. Duncan ${ }^{13}$ differentiates between the system's internal and external environment as follows:

- The internal environment consists of those relevant physical and social factors contained within the boundaries of the organization or specific decision unit, and are taken directly into consideration in the decision-making behaviour of that system's individuals.

- The external environment consists of those relevant physical and social factors outside the boundaries of the organization or specific decision unit that are taken directly into consideration.

Although Duncan's ${ }^{14}$ categorization of the internal and external environments provides a useful breakdown, he appears to have omitted a number of important components which constitute the environments. Environments may be composed of any one or all of a number of different items, but in general each particular organization will have its own relevant environment.

\section{Planning theories}

Woodburn ${ }^{15}$ suggests that the heart of any planning system is a company's annual budgets, which, in turn, may be phased into monthly operating budgets against which progress and performance may be monitored and controlled. Budgets, however, cannot be prepared without some form of guiding objectives established by management. The task of formulating objectives is, in turn, restricted by the constraints imposed by the organization's internal functional environment as well as by its external operating environment. The resource limitations of the internal environment, coupled with the uncertainty of the external environment, dictate the need for strategies to achieve the objectives. The nature and composition of these two environments and resulting strategies may further necessitate the preparation of longer range plans to achieve long-term objectives. The strategies and long range plans can finally be broken down into short and intermediate range plans which, in turn, can be converted into financial expectations 
in the form of operational budgets, thus forming a complete planning cycle.

From the broad framework suggested above, the corporate planning process is considered by Woodburn ${ }^{16}$ to be composed of the following five basic subprocesses:

(a) environmental scanning;

(b) formulation of objectives;

(c) strategic planning;

(d) long range planning;

(e) operational planning.

The nature of the corporate planning process is such that, although the subprocesses would normally be undertaken in the logical sequence shown above, the process itself is iterative and interactive, with many of the subprocesses being interdependent upon each other. Each of the five basic subprocesses is composed in turn of a set of components, the details of which would depend on a particular organization's requirements.

\section{Hypotheses}

In an attempt to develop and operationalize hypotheses below, the following general objectives and criteria expounded by Tukey ${ }^{17}$ will be borne in mind. The setting up of hypotheses will be regarded as a first stage in the scientific process and while these hypotheses will provide direction, the research will not set out with the intention of confirming them. These early hypotheses will be treated very flexibly since, in all probability, they will not be confirmed, but rather have served the purpose of providing direction for the research.

It will be recalled from the discussion on the findings of the 'Contingency Theory' that effective functioning organizations have structural characteristics which are in harmony with the characteristics of their operational environments. Woodburn ${ }^{18}$ in the development of his concept of the corporate planning process, shows that 'strategy' relates directly to an organization's transition from the open-endedness of the unbounded external environment to finite starting and planned productmarket positions. It follows from these observations that some relationship probably exists between strategic planning, the forms of organizational structures and participants' orientations, and the degree of certainty or uncertainty of the environment. This possible relationship leads logically to the statement of the following broad proposition.

Proposition: The extent and nature of an organization's involvement in the planning process is determined by the characteristics of the organization's internal environment and the degree of uncertainty of its external operational environment.

This proposition may be expanded into the following three detailed hypotheses by using the concepts of bureaucratic, mechanistic and organic organizations and their corresponding environmental connotations discussed earlier.

Hypothesis 1: Units of organizations whose structures and processes are generally 'bureaucratic', and which operate under stable and virtually certain environmental conditions (stable/homogeneous environment), can be expected to function exclusively on simple budgets with a complete disregard for strategic planning or any other elements of the corporate planning process. Hypothesis 2: Organizational units whose structures and processes are generally 'mechanistic' and which face relatively stable environmental conditions (stable/ heterogeneous or dynamic/homogeneous environments) will tend to utilize long-range planning as an adjunct to or extension of their normal annual budgeting process.

Hypothesis 3: A high level of involvement in strategic planning and an integrated approach to corporate planning can be expected in organizational units whose structures and processes are 'organic' and which face highly uncertain environmental conditions (dynamic/ heterogeneous environments).

\section{Operationalization and analyses}

\section{Organizational characteristics}

To operationalize the characteristics of an organization with its myriad interacting components it will be necessary to narrow down the focus by means of a simple categorization. For this purpose the fundamental characteristics of an organization will be assumed to stem from its basic structure, and organizational style or process of management operating within the structure. The specific operationalization of various measures of organizational structure will be based on an approach suggested by Sathe ${ }^{19}$ which appears to be the most comprehensively derived methodology availabe from the literature. As a result of a summary of major empirical studies on the dimensions of organizational structure, Sathe ${ }^{20}$ arrives at the following five dimensions:

(a) Hierarchy of authority (Centralization).

(b) Division of labour (Specialization, Functionalization).

(c) Rules and procedures (Formalization).

(d) Impersonality.

(e) Technical qualifications.

Sathe ${ }^{21}$ concludes from the literature that there is some agreement emerging that the three major dimensions of organizational structure are:

(i) centralization,

(ii) specialization, and

(iii) formalization.

To obtain measures of these three dimensions of organizational structure, use is made of questionnaire responses in a large sample survey. To obviate the difficulties inherent in deriving new scales it was decided, after a careful survey of the literature, to use the Pugh et al. ${ }^{22}$ scales, as abbreviated and tested by Inkson et $\mathrm{al}^{23}$. This method was selected from the more sophisticated approaches such as those by Samuel and Mannheim ${ }^{24}$ and Hage and Aiken, ${ }^{25}$ on the basis that the Inkson $e t a l .{ }^{26}$ approach involved obtaining information from one or a few top executives in an organization, rather than a large number of lower level individuals. For logistic reasons, the selection of this method was further considered justifiable in view of these dimensions being just a few of the many which would be required to be measured in the total research project.

Having measured the three structural dimensions of an organization, it is then possible to categorize the organizational style or process of management decision-making which takes place in that organization based on the following three distinctive systems of organizational style found in the literature:

- The 'bureaucratic' system attributable to Weber, ${ }^{27}$ which comprises a hierarchical structure, position, authority and rules for solving repetitive problems. This system thrives in a non-competitive, undifferentiated and stable environment, but collapses under environmental change. The dimensions of such an organization would reflect a high degree of centralization, very clear lines of demarcation in the division of labour (specialization) and very formal rules and procedures (formalization).

- The formal 'mechanistic' system which is associated with high effectiveness in relatively stable known environments. 
In mechanistic systems the problems and tasks facing the concern as a whole are subdivided into specialisms. The technical methods, duties and power associated with each functional role are clearly defined and a hierarchical command system is maintained. The dimensions of a mechanistic system are similar to those of a bureaucratic system but tend to be less rigid.

The relatively informal 'organic' system which is associated with high effectiveness in diverse unknown environments in which it is extremely difficult to anticipate the multiplicity of demands to which the organization may have to respond. Organic systems adapt to unstable conditions. Under such conditions problems and requirements for action arise which cannot be broken down and allocated among specialist roles within a clearly defined hierarchy. Jobs lose much of their formal definition in terms of procedures, duties, methods and powers. The dimensions of an organic system are clearly different from those of either a bureaucratic or mechanistic system. Here decisions tend to be decentralized without a clear hierarchy. No clear division of labour, specialization or functionalization is possible, and the lines of communication, rules and procedures tend to be lateral and very informal.

\section{Environmental characteristics}

With the structural dimensions and basic characteristics of an organization now identified, it is necessary to turn attention to the external operational environment. Very few reliable methods of operationalizing the environment are found in the literature. Of the few available, the Hayes ${ }^{28}$ approach was selected on the basis that the information required for this approach could easily be obtained by questionnaire responses.

Hayes ${ }^{29}$ suggests that environmental uncentainty is a perceptual phenomenon that is multidimensional. By comparison, the Thompson ${ }^{30}$ classification of the environment discussed earlier represents two summary dimensions of the concept. Treating the environment as a perceptual construct within the Thompson's ${ }^{31}$ four cell framework leads to considerable difficulties in operationalization. The Hayes ${ }^{32}$ method of operationalization is based on an interpretation of Thompson's ${ }^{33}$ reasoning of the two environmental dimensions.

The perceived number of factors in the subunits decision environment was employed by Duncan ${ }^{34}$ as his measure of homogeneity/heterogeneity. Thompson ${ }^{35}$ argues that the number of factors alone is inadequate fully to describe this dimension of the environment, but that the extensiveness of environmental influence on the functioning of the subunit is the critical component. A company may be exposed to a large number of suppliers, customers and competitors, but this diversity does not necessarily suggest problems for the subunit in handling these environmental sectors. Heterogeneity or complexity may only be implied if the potential actions and/or reactions of these groups require constant monitoring due to the unpredictability of their responses to changing conditions.

Using the foregoing argument, the homogeneous/heterogeneous dimensions may be operationalized on the basis of manager responses to a series of three questions:

(a) The first question deals with management's perception of the extent of competition encountered by the organization on a response scale from 'None' to 'A very great extent'.

(b) The second question, using the same four point response scale, requires managers to indicate the extent to which the activities of their various departments influence the organization's performance on the basis of a number of external economic and political factors as well as competitive factors, such as:

(i) product innovation,

(ii) quality,

(iii) delivery schedules,

(iv) customer service,

(v) responsiveness to customer requirements,

(vi) product price, and

(vii) company reputation.

(c) The third question, again on a four point scale, elicits the extent of influence of each of the above factors on the subunits planning activities.

By contrast with the above, the stable/dynamic dimension of the environment appears to be concerned with the perceived amount of, and ability to cope with, the changes taking place in the environment. Duncan ${ }^{36}$ operationalized this dimension as the frequency of change of the internal/external environmental factors identified on the homogeneity/heterogeneity dimension. Counting does not appear fully to capture the conceptual meaning of the construct and an alternative measure is required. The useful measure employed by Hayes, ${ }^{37}$ was adapted to focus on the effect of various competitive elements on the activities of the organization. To achieve this, respondents were requested to indicate their perceptions of the effect of each of the factors in (b) above on their planning activities. A four point response scale, from 'Tasks made far easier' to 'Tasks made far harder' was used.

These questions were combined and use made of the Hayes ${ }^{38}$ classification for determining environmental perceptions. The homogeneous/heterogeneous classification is based on the extent of competition/extent of influence responses while the stable/dynamic classification is graded on the easier/harder response.

From the dimensions operationalized above, it can be seen that the following information is required for each organization in order to carry out the categorizations.

- The Organization's Structural Parameters

- A measure of centralization of decision-making based on the level in the organization at which particular types of decisions are made.

- A measure of specialization of functions.

- A measure of formalization of procedures.

- The Organization's Environmental Parameters

- A measure of the degree of homogeneity/heterogeneity.

- A measure of the degree of static/dynamic.

In the research project upon which this paper is based, the above information was gathered as part of a comprehensive multiple choice answer type mail questionnaire on the uses of Strategic Planning.

\section{Planning and physical characteristics}

In addition to the dimensions outlined above, the following relevant physical characteristics were also captured in the questionnaire; age, number of employees, tumover and assets, as well as organizational form such as vertically integrated or conglomerate.

The degree of involvement in planning was operationalized by first breaking down the overall corporate planning process into its basic component parts. Each component part was in turn allocated a score, on a scale of 0 to 100 , in terms of its importance and depth of involvement in the process. The score assignments were derived on the basis of an analytical assessment of the importance of each item in relation to the overall process; the greater the importance, the higher was the score 
assigned: for example, a score of $\mathbf{4 0}$ was assigned for undertaking a 'Formal Search' as opposed to a score of 10 for 'Undirected Viewing'. Clearly such a procedure has arbitrary elements but was based on the explicit theoretical model developed by Woodburn. ${ }^{39}$ The individual scores were allocated in such a manner that a total maximum score for a particular table was 100 .

Table 1 shows the actual scores which were allocated to each aspect of planning. The assigned scores were summated for each of the six areas separately, as well as cumulatively to give an average overall score of involvement in the entire corporate planning process for each case. The six scores constituting the overall measure of involvement in corporate planning were then subjected to a reliability test. The six item scale yielded an Alpha reliability coefficient of 0,87140 and a standardized item Alpha of 0,87474 , indicating a reasonably high degree of reliability.

Table 1 Scoring system for planning involvement

\begin{tabular}{|c|c|c|}
\hline $\begin{array}{l}\text { Planning } \\
\text { component }\end{array}$ & Planning activity & $\begin{array}{l}\text { ¿.ore } \\
\text { assignment }\end{array}$ \\
\hline \multirow{5}{*}{$\begin{array}{l}\text { Methods of } \\
\text { environmental } \\
\text { scanning }\end{array}$} & Undirected viewing & 10 \\
\hline & Conditioned viewing & 20 \\
\hline & Informal search & 30 \\
\hline & Formal search & 40 \\
\hline & Maximum total score & 100 \\
\hline \multirow{5}{*}{$\begin{array}{l}\text { Application of } \\
\text { environmental } \\
\text { scanning }\end{array}$} & Strategic appraisal & 40 \\
\hline & $\begin{array}{l}\text { Assessment of opportunities } \\
\text { and threats }\end{array}$ & 20 \\
\hline & Identification of constraints & 20 \\
\hline & $\begin{array}{l}\text { Planning premises and } \\
\text { forecasts }\end{array}$ & 20 \\
\hline & Maximum total score & 100 \\
\hline \multirow{6}{*}{$\begin{array}{l}\text { Formulation of } \\
\text { objectives, goals } \\
\text { and targets }\end{array}$} & Participant objectives & 20 \\
\hline & Strategic objectives & 30 \\
\hline & Performance objectives & 20 \\
\hline & Goals & 20 \\
\hline & Targets & 10 \\
\hline & Maximum total score & 100 \\
\hline \multirow{7}{*}{$\begin{array}{l}\text { Facets of } \\
\text { strategic } \\
\text { planning }\end{array}$} & Strategy formulation & 30 \\
\hline & Portfolio of strategic & \\
\hline & alternatives & 40 \\
\hline & Resource analysis & 10 \\
\hline & Action programmes & 10 \\
\hline & Financial evaluation & 10 \\
\hline & Maximum total score & 100 \\
\hline \multirow{3}{*}{$\begin{array}{l}\text { Facets of } \\
\text { long range } \\
\text { planning }\end{array}$} & Long range plans & 60 \\
\hline & Intermediate range plans & 40 \\
\hline & Maximum total score & 100 \\
\hline \multirow{7}{*}{$\begin{array}{l}\text { Facets of } \\
\text { operational } \\
\text { planning }\end{array}$} & Operating budget & 20 \\
\hline & Cash budget & 20 \\
\hline & Capital budget & 20 \\
\hline & Tactical planning & 10 \\
\hline & Operational planning & 10 \\
\hline & Performance review & 20 \\
\hline & Maximum total score & 100 \\
\hline
\end{tabular}

The degree of formality of planning activities was similarly operationalized. Formality was measured simply in terms of five descriptive statements of formality. The scores assigned, on a scale of 0 to 100 , were again based on an assessment of formality for each descriptive statement. The formality scores for each of the five basic components were also summated and averaged to yield a measure of formality of the overall corporate planning process. The actual score assignment for each of the degrees of formality are shown in Table 2.

Table 2 Scoring system for formality of planning

\begin{tabular}{lc}
\hline Degree of formality of planning activity & $\begin{array}{c}\text { Score } \\
\text { assignment }\end{array}$ \\
\hline Activity not undertaken at all & 0 \\
Informally developed in the chief executive's mind & 10 \\
Informally developed and discussed by the Board of & 25 \\
Directors and/or top management & 50 \\
Broad concepts committed in writing & 75 \\
Reasonable level of detail prepared in writing & 100 \\
Very comprehensive and formally assembled into a \\
working document
\end{tabular}

The five scores constituting the overall measure of formality of the corporate planning process were also subjected to a reliability test. This test revealed that the five item scale had an Alpha reliability coefficient of 0,84820 and a standardized item Alpha of 0,84833 , indicating a reasonably high degree of reliability.

\section{Results}

\section{Cluster analysis of organizations}

Factor analysis was used to highlight certain inconsistencies in the three scales of centralization, formalization and specialization which were selected earlier to classify an organization's decision structure. These inconsistencies were eliminated by deleting certain items from the original scales which were shown to be irrelevant to this study.

The finally modified three scales were analysed for reliability. The 36 item modified scale yielded an Alpha reliability coefficient of 0,85139 and a standardized item Alpha coefficient of 0,87099 . The reliability of the modified scales were marginally lower than the full scales, but were considered to be far better general scales of measurement which could be applied equally to most organizations.

The modified scales discussed above were then factor analysed with the Varimax rotated factor matrix being limited to six factors. No significant loadings were found on the sixth factor so the process was repeated for five factors. This analysis indicated no significant loadings on the fifth factor so the process was again repeated for four factors. From the Varimax rotated factor matrix, the major loadings on the four factors were as follows:

Factor 1: SPECIALIZATION (Specialization of all activities) Factor 2: ADMINISTRATIVE CENTRALIZATION (Centralization of financial and administrative decisions)

Factor 3: FORMALIZATION (Formalization of all items)

Factor 4: STRATEGIC CENTRALIZATION (Centralization of marketing and organizational structure decisions). 
Whilst performing the above analysis, the computer program was also requested to generate four factor scores for each of the valid cases. These factor scores were composite scales that represented the theoretical dimensions associated with the respective factors. Having obtained these individual measures of the structural dimensions for each case, it was then possible logically to group or cluster organizations with similar characteristics.

Cluster analysis is a procedure by which it is possible to group entities together objectively on the basis of their similarities and differences. The purpose of cluster analysis is to discover the general properties of objects and the general types into which objects can be classed. Applying this technique, organizations were cluster categorized on the basis of their degrees of decision centralization, specialization and formalization indicated in their questionnaire responses.

\section{Cluster analysis of environments}

The first step in analysing the operational environment scales in the questionnaire was to perform a reliability analysis of both scales jointly to measure internal consistency. From this analysis it was found that the twenty-eight item scale yielded an Alpha reliability coefficient of 0,89095 and a standardized item Alpha coefficient of 0,89185 indicating a reasonably high degree of reliability. The two scales were then factor analysed jointly using principal factoring with iteration. This factor analysis yielded seven factors with Eigenvalues greater than 1,0 . An examination of the Varimax rotated factor matrix clearly indicated that the major loadings were across the first three factors with the other four factors sharing some of the loadings across the first three factors. On the strength of this, the factor analysis was repeated for six, five, four and three factors respectively. These analyses progressively loaded the previous factors onto the first three factors rather than onto any factor beyond the third. From the Varimax rotated factor matrix, the following factor loadings were found:

Factor 1: The homogeneous/heterogeneous dimension.

Factor 2: The stable/dynamic dimension.

Factor 3: Influence of the economic and political situation.

Whilst performing the above analysis, the computer program was also requested to generate three factor scores for the valid cases on the master file. These scores then formed the input for cluster analysis of the operational environment, which were similarly cluster categorized and named on the basis of their degrees of homogeneity/heterogeneity and stable/ dynamic dimensions.

\section{Characteristics of the clustered organizations}

For each of the clusters within each of the cluster sets, the cluster program also produced mean values of the factor scores for each cluster. These means were derived from the factor scores of the members in each cluster. The values of these mean scores were used as a rough guide for classifying the decision structure characteristics of each individual cluster. This was done by first determining the standard deviation for each of the weighted factors. One half of each standard deviation was then taken and compared with its respective factor mean for each cluster in turn. If a respective mean was positive and greater than the half standard deviation, that cluster was designated as comprising organizations with a high value on that particular factor. If, on the other hand, a mean was negative and less than its corresponding half standard deviation, that cluster was designated as comprising organizations with a low value on that particular factor. Mean values in the range from minus half a standard deviation to plus half a standard deviation designated clusters comprising organizations with medium values on that particular factor.

The total sample means and half standard deviations for each factor are shown below and will be used for all of the organizational cluster categories to be discussed.

\section{Factors}

\section{Total samples means}

Factor 1

Factor 2

Factor 3

Factor 4

$$
\begin{array}{r}
0,000 \\
-0,000 \\
0,000 \\
-0,000
\end{array}
$$

Half standard deviations

Starting with the lowest order, two cluster solution, and applying the classificatory process discussed above, the following decision structure characteristics were found:

Cluster 1: Decision structure:

- High specialization $(1,242 / 1,119)$

- Medium administrative centralization $(-0,105 /$ 1,043)

- Medium formalization $(0,172 / 0,759)$

- Medium strategic centralization $(-0,018 / 0,757)$

Cluster 2: Decision structure:

- Low specialization $(-3,305 / 1,119)$

- Medium administsrative centralization $(0,280 /$ 1,043)

- Medium-low formalization $(-0,457 / 0,759)$

- Medium strategic centralization $(0,049 / 0,757)$.

The respective factor means of the cluster members are shown in parentheses behind each characteristic so as to give an indication of the extent of the 'high', 'medium' and 'low' measures relative to the half standard deviations shown to the right of the factor mean and presented earlier. The two cluster solution presented above is seen to have been clustered mainly on the effects of the first factor, namely: specialization, with all the other factors contributing medium effects and as such represents a very coarse categorization. This categorization clearly indicated the need to examine the characteristics of higher order solutions, but before doing so, it will be useful to consider suitable terminology for assigning names to these and subsequent clusters.

Using the broad concepts and characteristics of organizational types suggested in the literature and discussed earlier, it is possible to name the clusters using the terminology for classifying organizations, that is: organic, mechanistic and bureaucratic. It is proposed to use these names very broadly and tentatively as a shorthand description, until more details have been established, as well as for relating the survey findings. The two cluster solution presented above will thus be very broadly considered to represent in Cluster 1 organizations displaying 'mechanistic' characteristics (because of the high specialization characteristic displayed) and those in Cluster 2 having 'organic' characteristics (because of the low specialization characteristic displayed).

The above classificatory process showed very broadiy that the two cluster solutions produced two classic categories of organizations, and as the number of clusters increased in the higher order solutions, considerably more information about the different types of organizations constituting the clusters was revealed. In the light of this finding, one-way analyses of variance of all relevant dependent variables with each cluster set as an independent variable was undertaken. The indepen- 
dent variable took the value of the cluster number which had been assigned to a particular case, for example, the independent variable for a five cluster set could take the value 1 to 5. For each of the cluster sets, the analyses indicated high statistical significance for the physical parameters such as age $(0,0039)$, number of employees $(0,0075)$, turnover $(0,0014)$ and assets $(0,0085)$, but no significance for variables such as maturity of organization $(0,1955)$, growth rate $(0,2401)$ or profitability $(0,6084)$.

Continuing the above processes with the three, four and five cluster solutions, it was found that the mean values of the significant variables for each cluster could be ranked in ascending order, and that the direction of this order between most variables was congruent. The 'best grouping' of the total sample of responding organizations appeared to comprise four clusters, two of which displayed organic traits, and two mechanistic traits. This categorization yielded the most consistent continuum for each of the physical and planning characteristics of the organizations. Higher order solutions yielded more organizational information, but at the expense of continuity in the continuum discussed above. For the purpose of conducting statistical tests relating the organi-ational characteristics to planning and other aspects, use will be made of the five cluster categorization as it provides a comprehensive and interesting segmentation of organizational forms.

The individual characteristics of the five clusters, ranked along the age/number of employees continuum, are shown below:

Cluster 2: Decision structure:

- Low specialization $(-3,590 / 1,119)$

- Low administrative centralization $(-1,582 /$ 1,043)

- Medium-low formalization (-0,694/0,759)

- Medium strategic centralization $(-0,055 / 0,757)$

Broad description of clustered organizations:

- Small decentralized organic.

Mean age:

- 38 years.

Cluster 5: Decision structure:

- Low specialization $(-2,933 / 1,119)$

- High administrative centralization $(2,210 / 1,043)$

- Medium formalization (-0,197/0,759)

- Medium strategic centralization $(0,137 / 0,757)$

Broad description of clustered organizations:

- Large centralized semi-organic.

Mean age:

- 41 years.

Cluster 4: Decision structure:

- High specialization $(1,192 / 1,119)$

- Low administrative centralization $(-1,256 /$ 1,043)

- Medium formalization $(0,241 / 0,759)$

- High strategic centralization $(2,002 / 0,757)$

Broad description of clustered organizations

- Centralized strategic, decentralized administrative mechanistic.

Mean age:

- 45 years.

Cluster 1: Decision structure:

- High specialization $(1,407 / 1,119)$

- High administrative centralization $(2,112 / 1,043)$

- Medium formalization $(0,020 / 0,759)$
- Medium strategic centralization $(0,069 / 0,757)$

Broad description of clustered organizations:

- Centralized mechanistic.

Mean age:

- 48 years.

Cluster 3: Decision structure:

- High specialization $(1,132 / 1,119)$

- Low administrative centralization $(-1,865 /$ 1,043)

- Medium formalization $(0,296 / 0,759)$

- Low strategic centralization $(-1,165 / 0,757)$

Broad description of clustered organizations:

- Decentralized mechanistic/bureaucratic.

Mean age:

- 58 years.

From the above discussion it clearly emerges that organizations can be displayed along a continuum ranging from the smallest and youngest to the largest and oldest. Decision characteristics indicated organic traits in the smaller, younger organizations and mechanistic/bureaucratic traits in the larger/older organizations. Expanding the cluster groups from two to five clearly indicated the changing profiles of organizations as they moved from one cluster to the next in their corporate growth. This same organizational continuum also revealed that, as the size and complexity of the organization increased, so did its degree of involvement in the various facets of corporate planning. The degree of formality of an organization's involvement in the various facets of corporate planning also increased as the organization's size and complexity increased. These increases along the continua can be clearly seen in Table 3.

Due to the strong influence of the basic physical parameters such as age, size, turnover and assets, it was necessary to examine the significance of the clustered organizations on planning involvement after removing these strong influences. To undertake this investigation, use was made of analysis of covariance. Covariates of age, number of employees, turnover and assets were inserted into the analysis so as to remove these extraneous variations from the dependent variable, thereby increasing measurement precision. Regression procedures were used to remove variation in the dependent variable due to one or more covariates, and a conventional analysis of variance was then performed on the 'corrected' scores. The results of this analysis showed that jointly the covariates were highly significant, but that only turnover was significant on its own. The significance of turnover can possibly be attributed to its being the 'best' overall measure of an organization's size. Some organizations are either very capital or labour intensive and in consequence these measures cannot be regarded as true representations of size. After the extraneous variations caused by the covariates had been removed, the main effects on planning involvement of the clustered organizations were still highly significant with a significance of less then 0,001 . This result indicated that as organizations increase in size and complexity, they increase their involvement in planning. It may be concluded from this finding that organizations progressively require more planning so as to co-ordinate and control the activities of increasingly complex organizational structures. In other words, planning is used as an 'integrative device' for 'holding together' increasingly complex organizational structures.

The above section has concentrated entirely on organizational characteristics and their relationship to the planning pro- 
Table 3 Planning characteristics of five cluster organizations

Five organizational clusters

\begin{tabular}{|c|c|c|c|c|c|}
\hline \multirow[b]{5}{*}{ Characteristics } & \multicolumn{5}{|c|}{ Five organizational clusters } \\
\hline & \multicolumn{2}{|c|}{ Organic traits } & \multicolumn{3}{|c|}{ Mechanistic traits } \\
\hline & Cluster 2 & Cluster 5 & Cluster 4 & Cluster 1 & Cluster 3 \\
\hline & $\begin{array}{c}\text { Small } \\
\text { decentralized } \\
\text { organic } \\
\text { organizations } \\
\end{array}$ & $\begin{array}{c}\text { Large } \\
\text { centralized } \\
\text { semi-organic } \\
\text { organizations }\end{array}$ & $\begin{array}{l}\text { Centralized } \\
\text { strategic, } \\
\text { decentralized } \\
\text { administrative } \\
\text { mechanistic } \\
\text { organizations }\end{array}$ & $\begin{array}{l}\text { Centralized } \\
\text { mechanistic } \\
\text { organizations }\end{array}$ & $\begin{array}{l}\text { Decentralized } \\
\text { mechanistic/ } \\
\text { bureaucratic } \\
\text { organizations }\end{array}$ \\
\hline & $N=59$ & $N=58$ & $N=62$ & $N=124$ & $N=118$ \\
\hline \multicolumn{6}{|l|}{ Physical: } \\
\hline Mean age & 38 & 41 & 45 & 48 & 58 \\
\hline Mean no. of employees & 6700 & 16050 & 32500 & 48450 & 49700 \\
\hline Mean turnover in $\mathbf{R}$-millions & 236 & 476 & 653 & 584 & 836 \\
\hline Mean assets in R-millions & 299 & 866 & 1908 & 1239 & 1891 \\
\hline \multicolumn{6}{|c|}{$\begin{array}{l}\text { Degrees of involvement in planning } \\
\text { activities } \\
\text { Mean scores on 0-100 scale }\end{array}$} \\
\hline Methods of scanning & 35 & 46 & 53 & 62 & 66 \\
\hline Application of scanning & 43 & 55 & 72 & $74+$ & 72 \\
\hline Formulation of objectives & 54 & 78 & 76 & $82+$ & 79 \\
\hline Strategic planning & 32 & 48 & 60 & $70+$ & 67 \\
\hline Long range planning & 29 & 46 & 62 & $70+$ & 68 \\
\hline Operational planning & 65 & 80 & 91 & 90 & 92 \\
\hline Overall corporate planning & 43 & 59 & 69 & $75+$ & 74 \\
\hline \multicolumn{6}{|c|}{$\begin{array}{l}\text { Degrees of formality of planning } \\
\text { activities } \\
\text { Mean scores on } 0-100 \text { scale }\end{array}$} \\
\hline Environmental scanning & 35 & 27 & 44 & 42 & 48 \\
\hline Formulation of objectives & 53 & 59 & 67 & 74 & 71 \\
\hline Strategic planning & 38 & 40 & 52 & 60 & 61 \\
\hline Long range planning & 34 & 43 & 61 & 62 & 63 \\
\hline Operational planning & 65 & 74 & 84 & 79 & 83 \\
\hline Overall corporate planning & 45 & 49 & 62 & 63 & 65 \\
\hline
\end{tabular}

$p<0,0001$

cess. It is now necessary to look at the operational environment in relation to the planning process and then examine the effects of these influences on the planning process.

\section{Characteristics of the environmental clusters}

The first step in determining the characteristics of the operational environment was to subject each of the cluster solutions previously selected, to one-way analyses of variance. The dependent variables selected for these analyses included all of the physical parameters describing the organization such as age, size, turnover and assets, as well as the degrees of involvement and formality scores for each of the various facets and total process of corporate planning.

No statistical significance was found across any of the clusters for any of the physical parameters of age, size, turnover or assets. High statistical significances were, however, found across the two and four clusters for the degrees of involvement in each of the various facets and total process of corporate planning. The degree of formality of each of the facets and total process of corporate planning was statistically significant for most of the items across the two cluster solution and to a lesser extent across the four cluster solution.
The above analyses of variance clearly indicated the usefulness of further examining only the two and four cluster environments and abandoning all other solutions. It will be recalled from the environmental analyses that the following three factors were derived:

Factor l: The homogeneous/heterogeneous dimension. Factor 2: The stable/dynamic dimension.

Factor 3: Influence of the economic and political situation.

Using the mean values of the weighted factor scores of the cluster members as a guide, the characteristics of the two and four cluster environments were determined along the same lines described for the organizational clusters. In this case, the means were regarded as continua of the homogeneous/heterogeneous and stable/dynamic dimensions. The more negative the mean of the first factor indicated the degree of homogeneity, while the more positive, the degree of heterogeneity. Likewise, the more negative the mean of the second factor indicated the degree of stability while the more positive indicated the degree of dynamism of the environment. For both the two and four cluster solution, factor three, which represented the economic and political situations, did not contribute strongly either way and was not used for the classification. 
The total sample means and half standard deviations for each factor are shown below and will be used for all of the environmetal cluster categorizations discussed in this section.

Total Sample Means Half Standard Deviations

$\begin{array}{lll}\text { Factor } 1 & 0,000 & 1,136 \\ \text { Factor } 2 & 0,000 & 0,947 \\ \text { Factor } 3 & 0,000 & 0,757\end{array}$

Starting with the two cluster solution, and applying the classificatory process discussed above, the following environmental characteristics were found. The resulting clusters are presented in order of their position along the certain/uncertain continuum rather than in cluster number order. As in the case with the organizational clusters, the respective factor means of the cluster members are shown in parentheses behind each characteristic so as to give an indication of the extent of the 'high', 'medium', and 'low' measures relative to the half standard deviation shown to the right of the factor mean and presented earlier.

Cluster 1: Dimensional characteristics:

- Low on homogeneous/heterogeneous continuum $(-2,375 / 1,136)$

- Medium-low on stable/dynamic continuum $(-0,252 / 0,947)$

- Medium on economic and political influence continuum $(0,079 / 0,757)$

Broad description of environment:

- Stable/homogeneous.

Cluster 2: Dimensional characteristics:

- High on homogeneous/heterogeneous continuum $(1,391 / 1,136)$

- Medium-high on stable/dynamic continuum $(0,148 / 0,947)$

- Medium on economic and political influence continuum $(0,046 / 0,757)$

Broad description of environment:

- Dynamic/heterogeneous.

In the two cluster solution shown above, the homogeneous/ heterogeneous dimension dominated. Cluster 1 organizations were operating in strongly homogeneous and slightly stable environments, whereas those in Cluster 2 were operating in strongly heterogeneous and slightly dynamic environments.

Applying the same classificatory process to the four cluster solution yielded the following characteristics which are again presented in order of their certain/uncertain continuum rather than in cluster number order.

Cluster 2: Dimensional characteristics:

- Low on homogeneous/heterogeneous continuum $(-5,599 / 1,136)$

- Low on stable/dynamic continuum $(-1,235 / 0,947)$

- Medium on economic and political influence continuum $(0,141 / 0,757)$

Broad description of environment:

- Stable/homogeneous.

Cluster 1: Dimensional characteristics:

- Low on homogeneous/heterogeneous continuum $(-1,557 / 1,136)$

- Medium on stable/dynamic continuum $(0,084 / 0,947)$

- Medium on economic and political influence continuum $(-0,268 / 0,757)$

Broad description of environment:

- Dynamic/homogeneous.

Cluster 3: Dimensional characteristics:

- High on homogeneous/heterogeneous continuum $(1,754 / 1,136)$

- Low on stable/dynamic continuum $(-1,760 / 0,947)$

- Medjum on economic and political influence continuum $(-0,069 / 0,757)$

Broad description of environment:

- Stable/heterogeneous.

Cluster 4: Dimensional characteristics:

- High on homogeneous/heterogeneous continuum $(1,191 / 1,136)$

- High on stable/dynamic continuum $(1,968 /$ 0,757 )

- Medium on economic and political influence continuum $(0,365 / 0,757)$

Broad description of environment:

- Dynamic/heterogeneous.

In the case of the four cluster solution, both the homogeneous/heterogeneous and stable/dynamic dimensions were strongly evident. Cluster 2 members displayed extremely strong homogeneity and strong stability. Cluster 1 members displayed strong homogeneity but only very slight dynamism. Cluster 3 displayed very strong heterogeneity and strong stability. Cluster 4 members displayed both strong heterogeneity and dynamism.

The two and four cluster groups discussed above were carefully examined and ranked in order of their increasing complexity and uncertainty to form the two continua shown in Table 4. Mean values of the statistically significant scores of involvement and degrees of formality of the various facets and total process of corporate planning were determined for each of the cluster groups within the two and four cluster solutions. These values were tabulated and are reproduced in Tabie 4 . From this Table it can immediately be seen that for each of the various planning activities the degrees of involvement increase as the complexity and uncertainty of the operational environment increase. This trend is clearly illustrated in both cases of the simple two cluster and more comprehensive four cluster categorizations of environments.

It can also be seen from Table 4 that the degree of formality of the various planning items increase from Cluster 1 to Cluster 2 in the case of the two cluster solution, but do not all increase uniformly in the four cluster solution. It is interesting to note from this tabulation of formality that the four cluster solution appears to suggest that when the environment becomes extremely complex and uncertain, that is dynamic/heterogeneous, the planning processes are forced to become less for$\mathrm{mal}$ so as to cope with the continual rapid changes taking place. The only exception to this is the 'long range planning' process in which its degree of formality increases uniformly $(46-50-54-57)$ as the degree of complexity and uncertainty increases. This may well be explained by the fact that long range decisions are less susceptible to shorter term fluctuations in the environment than are the other components of corporate planning.

An analysis of covariance was finally undertaken to ensure that no obvious extraneous variations were influencing the statistically significant relationship between planning involve- 
Table 4 Characteristics of two and four cluster environments

\begin{tabular}{|c|c|c|c|c|c|c|}
\hline \multirow[b]{3}{*}{$\begin{array}{l}\text { Planning } \\
\text { characteristics }\end{array}$} & \multicolumn{2}{|c|}{ Two clusters } & \multicolumn{4}{|c|}{ Four clusters ${ }^{b}$} \\
\hline & Cluster 1 & Cluster 2 & Cluster 2 & Cluster 1 & Cluster 3 & Cluster 4 \\
\hline & $\begin{array}{c}\text { Stable, } \\
\text { homogeneous } \\
\text { environment } \\
N=113\end{array}$ & $\begin{array}{c}\begin{array}{c}\text { Dynamic, } \\
\text { heterogeneous } \\
\text { environment }\end{array} \\
\mathrm{N}=193\end{array}$ & $\begin{array}{c}\text { Siable, } \\
\text { homogeneous } \\
\text { environment } \\
N=18\end{array}$ & $\begin{array}{c}\begin{array}{c}\text { Dynamic, } \\
\text { homogeneous } \\
\text { environment }\end{array} \\
\mathbf{N}=107\end{array}$ & $\begin{array}{c}\begin{array}{c}\text { Stable, } \\
\text { heterogeneous } \\
\text { environment }\end{array} \\
\mathbf{N}=92\end{array}$ & $\begin{array}{c}\begin{array}{c}\text { Dynamic } \\
\text { heterogeneous } \\
\text { environment } \\
N=89\end{array}\end{array}$ \\
\hline \multicolumn{7}{|l|}{$\begin{array}{l}\text { Degrees of involvement in } \\
\text { planning activities } \\
\text { Mean scores on 0-100 scale }\end{array}$} \\
\hline Methods of scanning & 47 & 58 & 47 & 49 & 57 & 57 \\
\hline Application of scanning & 53 & 68 & 51 & 53 & 67 & 72 \\
\hline Formulation of objectives & 67 & 78 & 66 & 68 & 74 & 83 \\
\hline Strategic planning & 48 & 62 & 46 & 50 & 59 & 64 \\
\hline Long range planning & $\$ 1$ & 59 & 44 & 53 & 57 & 62 \\
\hline Operational planning & 77 & 85 & 76 & 78 & 84 & 86 \\
\hline Overall corporate planning & 57 & 68 & 55 & 58 & 66 & 71 \\
\hline \multicolumn{7}{|l|}{$\begin{array}{l}\text { Degrees of formality of } \\
\text { planning activities } \\
\text { Mean scores on 0-100 scale }\end{array}$} \\
\hline Environment scanning & 36 & 43 & 28 & 38 & 43 & 43 \\
\hline Formulation of objectives & 58 & 67 & 51 & 60 & 69 & 66 \\
\hline Strategic planning & 44 & 55 & 36 & 46 & 59 & si \\
\hline Long range planning & 50 & 55 & 46 & 50 & 54 & 57 \\
\hline Operational planning & 75 & 76 & 79 & 76 & 75 & 76 \\
\hline Overall corporate planning & 53 & 59 & 48 & 54 & 60 & 59 \\
\hline
\end{tabular}

$p<0,002, b p<0,02$

ment and the degree of environmental uncertainty determined earlier. This analysis was undertaken with the total planning involvernent score as dependent variable, the four cluster environmental categorization as an independent variable in which values from 1 to 4 represented a particular case's environmental cluster number, and the physical parameters of organizational age, number of employees, turnover and assets as covariates. The results of this analysis of variance and covariance showed that, jointly, the physical parameter covariates were significant $(0,001)$, but that only turnover was significant $(0,013)$ on its own. The turnover significance again manifested itself as a measure of size as was the case earlier in the analysis, with the organizational clusters as independent variable. It could further be seen that, after the extraneous variations caused by the covariates had been removed, the main effects of the four cluster environments on planning involvement were still signifcant at 0,028 .

From the above analysis of the operational environment, it was seen that the degree of involvement by organizations in the various facets of corporate planning increased as the complexity and uncertainty of the environment increased. It will be recalled that the degree of involvement by organizations in the various facets of corporate planning also increased as the size and complexity of the organization increased. These two relationships necessitated performing a two-way analysis of variance and covariance to ascertain the significance of their inter-relationships with planning.

Joint effects of organizational and environmental clusters on planning

To determine the joint effects of organizational and environmental clusters on the degree of an organization's involvement in corporate planning, a two-way analysis of variance and covariance was undertaken. In this analysis the dependent variable was again the total planning involvement score, the clustered organizational and environmental categorizations were both independent variables, and the organizational age, number of employees, turnover and assets again covariates. From the results of this analysis it was again found that jointly the covariates were sigificant, but that only turnover was significant on its own for the reasons suggested earlier. It was also found that after the extraneous variations caused by the covariates had been removed, the joint main effects of the organizational and environmental clusters on planning involvement were highly significant (less than 0,001 ), but individually only the organizational clusters were significant (less than $0 ; 001$ ) while the environmental clusters lost significance $(0,069)$. Further, the two-way interaction effect between the organizational and environmentnal clusters was not significant $(0,582)$.

These results have a number of important implications. Firstly, turnover emerged as a strong measure of an organization's size since it cut across other indicators such as capital and labour intensity. Organizational size in turn had a strong bearing on an organization's degree of involvement in the overall corporate planning process. When considered separately, organizational and environmental cluster categorizations were significantly related to the degree of an organization's involvement in planning, but when considered together, the organizational characteristics emerged considerably stronger with their influence on planning than did the degree of environmental uncertainty. Finally, the organizational characteristics were not dictated by the degree of environmental uncertainty, neither did the organizational characteristics influence the degree of uncertainty of the environment, or vice versa. 


\section{Discussion}

As could be expected from the philosophy of Tukey, ${ }^{40}$ which was presented earlier, the actual research results indicated differences from those suggested by the hypotheses which had been established to provide direction for the research. The findings obtained from the survey research suggested that it would be necessary to modify the original hypotheses substantially so as more accurately to present the situation found in practice. Each of the hypotheses will be discussed below and with the aid of the survey results, modified into a new set of more representative propositions.

\section{Planning integration and organizational differentiation}

From the various analyses discussed above, it can be concluded that while environmental uncertainty does play a part in determining the degree of an organization's involvement in the corporate planning process, the size and complexity of the organization itself plays a stronger and more dominant role in dictating the degree of involvement. Planning appears to become a powerful internal integrator of complex organizations, rather than a technique with which to cope with external environmental uncertainty.

In the discussion on the contingency theory earlier, brief mention was made of the concepts of differentiation and integration. Since it has been suggested from the results of this survey that planning appears to become an integrative device under certain conditions, it will be useful at this stage to review briefly the concepts of differentiation and integration before proceeding to discuss the survey results and their bearing on these concepts. Lorsch \& Allen ${ }^{41}$ suggest the following definitions for these concepts:

'Differentiation is the difference in behaviour, cognitive

and emotional orientations, and ways of organizing

work which develop among managers in different

organizational units as each of these units copes with

its part of the organization's total environment.'

'Integration is the quality of collaboration which exists

among departments required to achieve unity of effort

by the environment.'

Lorsch \& Allen ${ }^{42}$ suggest that the concepts of differentiation and integration offer a useful and highly efficient means of exploring the management issues posed by the patterns of environmental diversity and interdependence faced by multidivisional organizations. By extending the use of these concepts from single-product organizations to multidivisional firms, it becomes possible to use a single conceptual framework for understanding the functioning of multiple levels of a complex organization.

To relate the survey findings to differentiation and integration concepts, the actual results will first be examined in terms of the organizational structures found, the types of environments in which they operate and finally the areas of planning engaged upon by the various structural forms of organization operating in the different environments.

\section{Structural influences}

It will be recalled that the clustering technique clearly indicated a continuum of organizational characteristics which were revealed by the specific measures of centralization, formalization and specialization used for the clustering. The detailed characteristics of each cluster were indicated in terms of 'high', 'medium' and 'low' statistical measures of these three dimensions. As a convenient 'short-hand' and for ease of referring to these clusters, use was made of the broad concepts of 'organic', 'mechanistic', 'bureaucratic' and subsets thereof to name the clusters.

The statistically significant five-cluster solution revealed the most interesting organizational structure continuum. In the five-cluster continuum (see details under subheading: 'Characteristics of the clustered organizations'), the first two clusters displayed low specialization followed hy high specialization in the other three clusters. The formalization of the first cluster was medium-low, followed by medium for the other clusters. The most interesting dimension, however, was the administrative centralization. This dimension oscillated from 'low' to 'high' as each cluster moved along the continuum. This statistically significant finding would seem to suggest that, as organizations increase in size and complexity, they enter growth phases in which a need arises to centralize decisions to integrate the organization. Once stability is achieved, decisions then tend to become decentralized until growth and further complexity again demand increased centralization to integrate the more diverse organization. This aspect can be clearly seen in Table 5 where the integrative needs of certain forms of organizations can be seen, for example, there are more of the simple, single independent organizations in the two decentralized clusters (Clusters 2 and 4) with chi-square statistically significant at the 0,02 level, and more of the complex diversified major/multiple interdependent organizations in the two centralized clusters (Clusters 5 and 1) with chi-square statistically significant at the 0,05 level.

Of particular interest, is the high concentration $(21,4 \%)$ of vertically integrated organizations found in Cluster 4 and the dominance $(50,0 \%)$ of multiple interdependent organizations in Cluster 1. In the case of the vertically integrated organizations, the integrative needs are clearly strategic centralization, rather than administrative centralization, whereas in the case of the multiple interdependent companies, strong administrative centralization is required. From the above significant findings it is now possible to construct with confidence the following basic proposition embodying organizational structure.

Organizations tend to require different internal structural characteristics which may be portrayed along a continuum representing, at the one end, young, small, simple organizations through to older, large, complex organizations, at the other end of the continuum. As the size and complexity of organizations increase, their characteristics change so as to meet their more complex differentiative or integrative needs.

In addition to changing the characteristics of the internal decision structure along the continuum to achieve integration, it can be seen from Table 3 that organizations also increase their involvement in planning as their size and complexity increase. The scores of all the various planning activities were highly significant across the five organizational clusters, each having $F$ probabilities of less than 0,0001 . This finding suggests that planning is an important integrative device. This integrative function of planning is clearly seen in Table 3, Cluster 1, where the scores of involvement in many of the activities of planning (indicated by + symbols in the table) exceed those for even the last cluster on the continuum, that is Cluster 3. The peaks in these scores of involvement in Cluster 1 coincide with the strong integrative structural characteristics displayed by the cluster. The high specialization and administrative centralization characteristics, as measured by the scales used in this project, both contain strong integrative activities. These significant findings confidently suggest the following basic pro- 
Table 5 Structural and environmental characteristics of five cluster organizations

\begin{tabular}{|c|c|c|c|c|c|}
\hline \multirow{5}{*}{$\begin{array}{l}\text { General } \\
\text { characteristics }\end{array}$} & \multicolumn{5}{|c|}{ Five organizational clusters } \\
\hline & \multicolumn{2}{|c|}{ Organic traits } & \multicolumn{3}{|c|}{ Mechanistic traits } \\
\hline & Cluster 2 & Cluster 5 & Cluster 4 & Cluster 1 & Cluster 3 \\
\hline & $\begin{array}{c}\text { Small } \\
\text { decentralized } \\
\text { organic } \\
\text { organizations } \\
\end{array}$ & $\begin{array}{c}\text { Large } \\
\text { centralized } \\
\text { semi-organic } \\
\text { organizations }\end{array}$ & $\begin{array}{l}\text { Centralized } \\
\text { strategic, } \\
\text { decentralized } \\
\text { administrative } \\
\text { mechanistic } \\
\text { organizations }\end{array}$ & $\begin{array}{c}\text { Centralized } \\
\text { mechanistic } \\
\text { organizations }\end{array}$ & $\begin{array}{c}\text { Decentralized } \\
\text { mechanistic/ } \\
\text { bureaucratic } \\
\text { organizations }\end{array}$ \\
\hline & $N=59$ & $N=58$ & $N=62$ & $N=124$ & $N=118$ \\
\hline \multicolumn{6}{|l|}{ Physical: } \\
\hline Mean age & 38 & 41 & 45 & 48 & 58 \\
\hline Mean no. of employees & 6700 & 16050 & 32500 & 48450 & 49700 \\
\hline Mean surnover in R-millions & 236 & 476 & 653 & 584 & 836 \\
\hline Mean assets in R-millions & 299 & 866 & - 1908 & 1239 & 1891 \\
\hline Structural: & $\%$ & $\%$ & $\%$ & $\%$ & $\%$ \\
\hline Single independent unit & 27,3 & 8,3 & 14,3 & 2,6 & 3,8 \\
\hline Multiple interdependent unit & 38,6 & 30,6 & 42,9 & 50,0 & 36,7 \\
\hline Vertically integrated company & 6,8 & 13,9 & 21.4 & 10,3 & 13,9 \\
\hline Diversified major company & 18,2 & 41,7 & 26,2 & 26,9 & 32,9 \\
\hline Conglomerate company & 13,6 & 13,9 & 11,9 & 20,5 & 21,5 \\
\hline Environment: & $\%$ & $\%$ & $\%$ & $\%$ & $\%$ \\
\hline \multicolumn{6}{|l|}{ Two clusters } \\
\hline Stable, homogeneous & 51,4 & 46,4 & 31,6 & 24,4 & 35,9 \\
\hline Dynamic, heterogeneous & 48,6 & 53,6 & 68,4 & 75,6 & 64,1 \\
\hline
\end{tabular}

$p<0,05$

position, which embodies organizational structure and planning involvement.

As organizations increase in size and complexity, they tend to increase their use of corporate planning as an integrative device.

\section{Environmental influences}

It will be recalled from the discussion on the simple two cluster categorization of environments that the homogeneous/heterogeneous dimension predominated, whereas in the more comprehensive four cluster categorization, both the homogeneous/ heterogeneous and stable/dynamic dimensions were strongly evident. A cross-tabulation analysis between the five organizational clusters and the two and four environmental clusters indicated that the chi-square was statistically significant at the 0,04 level for the two environmental clusters but that there was statistical independence between the five organizational clusters and four environmental clusters. This latter observation is in line with that found earlier where the two-way interaction effect between the five organizational and four environmental clusters was found to be not significant.

In Table 5 it can be seen that the strong integrative needs previously identified for Cluster 1 are caused by a predominance of the two cluster solution members operating in a heterogeneous environment. Further, it is interesting to note that these findings coincide with those of Lorsch \& Allen ${ }^{43}$ who suggested that conglomerate firms tended to operate in higher environmental uncertainty while vertically integrated firms tended to operate under lower environmental uncertainty. In Table 5 it can be seen that a predominance $(21,4 \%)$ of vertically integrated companies inhabit Cluster 4 and that $68,4 \%$ of this cluster's (No. 4) members operated in a heterogeneous environment compared to Cluster 1 , containing $(20,5 \%)$ conglomerate companies, where $75,6 \%$ operated in heterogeneous environments. In general, it can be further seen in Table 5 that the larger complex organizations operated in the more heterogeneous environments. The statistical significance found between the two environmental clusters and the five organizational clusters confidently suggest the following basic proposition relating the structure of organizations to their operational environment.

As organizations increase in size, and as their structures become more complex, they tend to operate in the more complex heterogeneous part of a dichotomized environment.

Table 4 clearly shows that, as the operational environment becomes more complex, for both the two and four cluster solutions, organizations increase their involvement in corporate planning. The overall scores of involvement in corporate planning, which were determined in a one-way analysis of variance, had an $F$ probability of 0,0023 for the two environmental clusters and 0,0222 for the four environmental clusters. This significant finding may be stated with confidence in the following form as a basic proposition.

Organizations which operate in increasingly complex operational environments tend to increase their degree of involvement in corporate planning.

The four basic propositions developed above from statistically significant results, may now be combined into one overall summary proposition, which provides a representative picture.

The greater the differentiation and environmental uncertainty caused by growth, diversification and organizational complexity, the greater become the in- 
tegrative needs provided by the range of facilities of corporate planning.

\section{Conclusions}

The author believes that the research upon which this paper was based has made a number of important contributions to current knowledge on the structure of organizations and environments and their influences on the application of corporate strategic planning.

The application of cluster analysis techniques for the categorization of organizations and environments resulted in the discovery of an age/size continuum containing the changing profiles of organizations at various stages of their corporate growth. The results of this process also led to the development of an improved scale for the measurement of the various dimensional characteristics of organizations.

Most of the findings from this research were based on the measures of organizational structure and environmental uncertainty. The measures used were based on previously applied and tested scales which had to be modified to suit this project. As such, the results obtained may have contained certain inconsistencies, although the large balanced sample used and high statistical significances probably reduced these inadequacies. These possible limitations may have distorted the categorizations of organizations and environments. Firstly, the organizations were categorized on the basis of three measures of their characteristics, namely: centralization, formalization and specialization. By their very nature, these measures may have shown that the larger organizations were more centralized or decentralized than the smaller organizations because these characteristics are inherent for the efficient co-ordination and control required for such organizations to function. Second$l y$, although the measures of environmental uncertainty classified the environment into the two dimensions of stable/dynamic and homogeneous/heterogeneous, much depended on how an organization perceived itself at a particular point in time. Smaller companies may well have perceived their environments as being stable/homogeneous because of their narrow field of activity, while the larger multinational organization, which tended to operate in higher growth areas, may have perceived their environments as being more dynamic/heterogeneous.

The limitations identified above suggest the need for the development of alternative and possibly more consistent measures for the structural characteristics of organizations. Likewise, a need exists for an improved scale of environmental uncertainty which embodies additional areas such as number of different products, markets and technologies with which an organization has to deal. A better measure of the environment would permit the rigorous verification of whether the formality of an organization's planning activities decreased under operating conditions of extreme uncertainty, as was tentatively suggested by this research.

Despite the possible limitations suggested above, the analyses of the survey results, based on a wide cross-section of over 500 companies, have clearly indicated that while the business environment does play a part in determining an organization's involvement in the total corporate planning process, it is really the complexity of the organization itself which dictates the degree of involvement.

This survey has revealed a new facet previously ignored in the classic concept of corporate planning. In fact, corporate planning now appears to be primarily a powerful internal in- tegrator of complex differentiated organizations, and only secondarily a management technique for coping with uncertain future business environments.

\section{References}

1. The substance of this article is based on research undertaken by Dr T.L. Woodburn, under the supervision of Prof. D.C. Limerick and Dr C.L. Suzman, and approved for the Ph.D. degree by the Faculty of Commerce, University of the Witwatersrand, Johannesburg

2. Lawrence, P.R. \& Lorch, J.W. Organization and environment Homewood, Hlinois: Richard D. Irwin, Inc. 1970, 279 pp.

3. Emery, F.E. \& Trist, E.L. The casual texture of organizational environments, Human Relations, vol.18, 1965, p.21.

4. Thompson, J.D. Organizations in action. New York: McGrawHill, 1967.

5. Lawrence \& Lorch, op. cit.

6. Emery \& Trist, op. cit.

7. Ibid.

8. Thompson, op. cit.

9. Ibid.

10. March, J.J. \& Simon, H.A. Organizations. New York: Wiley \& Sons, 1958.

11. Duncan, R.B. Characteristics of Organizational Environments and Perceived Environmental Uncertainty. Admin. Sci. Q., vol.17, Sept. 1972, p.313.

12. Ibid.

13. Ibid.

14. Ibid

15. Woodburn, T.L. Corporate planning in South African Organizations, (Unpublished Doctoral thesis, Johannesburg: University of the Witwatersrand, 1979,384 pp.)

16. Ibid.

17. Tukey, J.W. Analysing data: sanctification or detective work, Am. Psychol., vol.24, 1969, p.83

18. Woodburn, op, cit.

19. Sathe, V. Measures of organizational structure: a conceptual distinction between two major approaches. Undated, pp.173-175. (Paper from Sathe, V. Georgia Institute of Technology.)

20. Ibid.

21. Ibid.

22. Pugh, D.S., Hickson, D.J., Hinings, C.R. \& Turner, C. Dimensions of Organization Structure, Admin. Sci. Q., vol.13, no.1, June 1968, p.65.

23. Inkson, J.H.K., Pugh, D.S. \& Hickson, D.J. Organization con text and structure: an abbreviated replication, Admin. Sci. $Q$., vol.15, no.3, Sept. 1970, p.318.

24. Samuel, Y. \& Manntheim, B.F. A multidimensional approach toward a Typology of Bureaucracy, Admin. Sci. Q., vol.15, no.3 Sept. 1970, p.216.

25. Hage, J. \& Aiken, M. Relationships of centralization to other structural properties, Admin. Sci.Q., vol.12, 1967.

26. Inkson et al, op. cit.

27. Weber, M. Legitimate Authority and Bureaucracy. Organisation Theory. (Ed.) Pugh, D.S. Harmondsworth, Middlesex, England: Penguin Books Limited, 1971.

28. Hayes, D.C. Aspects of a contingency theory of managerial accounting. Working paper no.377, University of British Columbia, Vancouver, B.C. Canada, March 1976, 36 pp.

29. Ibid.

30. Thompson, op cit.

31. Ibid.

32. Hayes, op. cit.

33. Thompson, op cit.

34. Duncan, op cit.

35. Thompson, op. cit.

36. Duncan, op. cit.

37. Hayes, op cit.

38. Ibid.

39. Woodburn, op. cit.

40. Tukey, op. cit.

41. Lorsch, J.W. \& Allen III, S.A. Managing diversity and interdependence, 1st ed., Boston: Harvard University Press, 1973, p. 265 .

42. Ibid.

43. Ibid 
Appendlx I General characteristics of five cluster organizations

\begin{tabular}{|c|c|c|c|c|c|}
\hline \multirow{5}{*}{$\begin{array}{l}\text { General } \\
\text { characteristics }\end{array}$} & \multicolumn{5}{|c|}{ Five organizational clusters } \\
\hline & \multicolumn{2}{|c|}{ Organic traits } & \multicolumn{3}{|c|}{ Mechanistic traits } \\
\hline & Cluster 2 & Cluster 5 & \multirow{2}{*}{$\begin{array}{c}\text { Cluster } 4 \\
\text { Centralized } \\
\text { strategic, } \\
\text { decentralized } \\
\text { administrative } \\
\text { mechanistic } \\
\text { organizations }\end{array}$} & Cluster 1 & Cluster 3 \\
\hline & $\begin{array}{c}\text { Small } \\
\text { decentralized } \\
\text { organic } \\
\text { organizations }\end{array}$ & $\begin{array}{c}\text { Large } \\
\text { centralized } \\
\text { semi-organic } \\
\text { organizations }\end{array}$ & & $\begin{array}{l}\text { Centralized } \\
\text { mechanistic } \\
\text { organizations }\end{array}$ & $\begin{array}{c}\text { Decentralized } \\
\text { mechanistic/ } \\
\text { bureaucratic } \\
\text { organizations }\end{array}$ \\
\hline & $N=59$ & $N=58$ & $N=62$ & $N=124$ & $N=118$ \\
\hline Physical: & & & & - & \\
\hline Mean age & 38 & 41 & 45 & 48 & 58 \\
\hline Mean no. of employees & 6700 & 16050 & 32500 & 48450 & 49700 \\
\hline Mean iurnover in $\mathrm{R}$-mitlions & 236 & 476 & 653 & 584 & 836 \\
\hline Mean assets in R-millions & 299 & 866 & 1908 & 1239 & 1891 \\
\hline Structural: & $\%$ & $\%$ & $\%$ & $\%$ & $\%$ \\
\hline Single independent unit & 27,3 & 8,3 & 14,3 & 2,6 & 3,8 \\
\hline Multiple interdependent unit & 38,6 & 30,6 & 42,9 & 50,0 & 36,7 \\
\hline Vertically integrated company & 6,8 & 13,9 & 21,4 & 10,3 & 13,9 \\
\hline Diversified major company & 18.2 & 41,7 & 26,2 & 26,9 & 32,9 \\
\hline Conglomerate company & 13,6 & 13,9 & 11,9 & 20,5 & 21,5 \\
\hline Ownership: & $\%$ & $\%$ & $\%$ & $\%$ & $\%$ \\
\hline Individual(s) & 40,7 & 19,0 & 23,0 & 17,1 & 13,6 \\
\hline Institution(s) & 5,1 & 6,9 & 23,0 & 9,8 & 16,9 \\
\hline Local shareholders & 44,1 & 51,7 & 55.7 & 65,9 & 65,3 \\
\hline Overseas shareholders & 10,2 & 25,9 & 14.8 & 28,5 & 33,1 \\
\hline International parent co. & 18,6 & 34,5 & 41,0 & 32,5 & 32,2 \\
\hline Municipal authority & 0,0 & 0,0 & 0,0 & 0,0 & 0,8 \\
\hline Government & 0,0 & 0,0 & 0,0 & 1,6 & 4,2 \\
\hline Activity segments: & $\%$ & $\%$ & $\%$ & $\%$ & $\%$ \\
\hline Agriculture, forestry, hunting, fishing & 16,7 & 15,7 & 8,2 & 11,0 & 14,0 \\
\hline Mining and quarrying & 9,3 & 5,9 & 18,0 & 12,7 & 17,5 \\
\hline Manutacturing & 51,9 & 64,7 & 52,5 & 63,6 & 65,8 \\
\hline Electricity, gas and water & 1,9 & 5,9 & 1,6 & 3,4 & 6,1 \\
\hline Construction & 13,0 & 5,9 & 8,2 & 13,6 & 16,7 \\
\hline & & & & & \\
\hline $\begin{array}{l}\text { and accommodation services } \\
\text { Transport, storage and postal services }\end{array}$ & 27,8 & $\begin{array}{r}35,3 \\
7,8\end{array}$ & $\begin{array}{r}21,3 \\
6,6\end{array}$ & $\begin{array}{l}28,0 \\
11,0\end{array}$ & $\begin{array}{l}21,9 \\
11,4\end{array}$ \\
\hline & 9,3 & & & & \\
\hline $\begin{array}{l}\text { business services } \\
\text { Community, social and personal }\end{array}$ & 14,8 & 13,7 & 23,0 & 12.7 & 20,2 \\
\hline $\begin{array}{l}\text { Community, social and personal } \\
\text { services }\end{array}$ & 3,7 & 5,9 & 0,0 & 0,8 & 2,6 \\
\hline Eavironment: & $\%$ & $\%$ & $\%$ & $\%$ & $\%$ \\
\hline Two clusters & & & & & \\
\hline Stable, homogeneous & $\begin{array}{l}51,4 \\
48,6\end{array}$ & 46,4 & 31,6 & 24,4 & 35,9 \\
\hline Dynamic, heterogeneous & 48,6 & 53,6 & 68,4 & 75,6 & \\
\hline $\begin{array}{l}\text { Four clusters } \\
\text { Stable, homogeneous }\end{array}$ & & & & 1,2 & 3,8 \\
\hline $\begin{array}{l}\text { Stable, homogeneous } \\
\text { Dynamic, homogeneous }\end{array}$ & $\begin{array}{l}11,4 \\
40,0\end{array}$ & $\begin{array}{r}3,6 \\
42,9\end{array}$ & $\begin{array}{r}7,9 \\
28,9\end{array}$ & 29,3 & $\begin{array}{l}37,0 \\
37,2\end{array}$ \\
\hline Dynamic, homogeneous & $\begin{array}{l}40,0 \\
28,6\end{array}$ & $\begin{array}{l}42,9 \\
39,3\end{array}$ & $\begin{array}{l}28,9 \\
34,2\end{array}$ & 30,5 & 26,9 \\
\hline & $\begin{array}{l}28,6 \\
20,0\end{array}$ & $\begin{array}{l}39,3 \\
14,3\end{array}$ & 28,9 & 39,0 & 32,1 \\
\hline $\begin{array}{l}\text { Dynamic, heterogeneous } \\
\text { Degrees of involvement in planning }\end{array}$ & & & & & \\
\hline $\begin{array}{l}\text { Degrees of involvement in planging } \\
\text { activities } \\
\text { Mean scores on } 0-100 \text { scale }\end{array}$ & & & & & \\
\hline Methods of scanning & 35 & 46 & 53 & 62 & 66 \\
\hline Application of scanning & 43 & 55 & 72 & 74 & 72 \\
\hline Formulation of objectives & 54 & 78 & 76 & 82 & 79 \\
\hline Strategic planning & 32 & 48 & 60 & 70 & 67 \\
\hline Long range planning & 29 & 46 & 62 & 70 & 68 \\
\hline Operational planning & 65 & 80 & 91 & 90 & 92 \\
\hline Overall corporate planning & 43 & 59 & 69 & 75 & 74 \\
\hline Degrees of formality of planning & & & & & \\
\hline $\begin{array}{l}\text { activities } \\
\text { Mean scores on } 0-100 \text { scale }\end{array}$ & & & & & \\
\hline Environmental scanning & 35 & 27 & 44 & 42 & 48 \\
\hline Formulation of objectives & 53 & 59 & 67 & 74 & 71 \\
\hline Strategic planning & 38 & 40 & 52 & 60 & 61 \\
\hline Long range planning & 34 & 43 & 61 & 62 & 63 \\
\hline Operational planning & 65 & 74 & 84 & 79 & 83 \\
\hline Overall corporate planning & 45 & 49 & 62 & 63 & 65 \\
\hline
\end{tabular}


Appendix II Planning characteristics of five cluster organizations

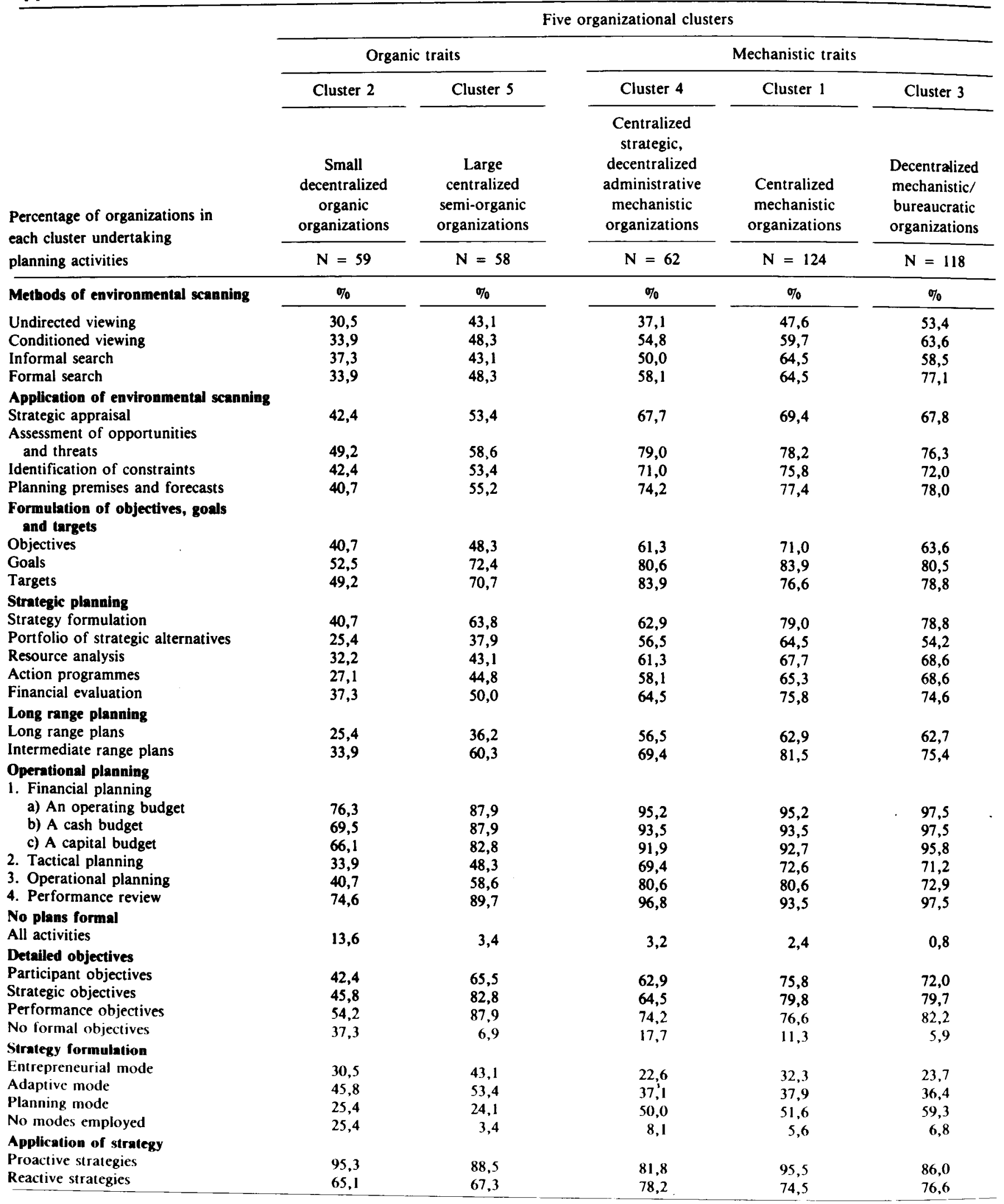


Appendix III Planning characteristics of two and four cluster environments

\begin{tabular}{|c|c|c|c|c|c|c|}
\hline \multirow{4}{*}{$\begin{array}{l}\text { Percentage of organizations } \\
\text { in each cluster undertaking } \\
\text { planning activities }\end{array}$} & \multicolumn{2}{|c|}{ Two clusters } & \multicolumn{4}{|c|}{ Four clusters } \\
\hline & Cluster I & Cluster 2 & Cluster 2 & Cluster 1 & Cluster 3 & Cluster 4 \\
\hline & $\begin{array}{c}\text { Stable, } \\
\text { homogeneous } \\
\text { environment }\end{array}$ & $\begin{array}{c}\text { Dynamic, } \\
\text { heterogeneous } \\
\text { environment }\end{array}$ & $\begin{array}{c}\text { Stable, } \\
\text { homogeneous } \\
\text { environment }\end{array}$ & $\begin{array}{l}\text { Dynamic, } \\
\text { heterogeneous } \\
\text { environment }\end{array}$ & $\begin{array}{l}\text { Stable, } \\
\text { heterogeneous } \\
\text { environment }\end{array}$ & $\begin{array}{c}\text { Dynamic, } \\
\text { heterogeneous } \\
\text { environment }\end{array}$ \\
\hline & $N=113$ & $N=193$ & $N=18$ & $N=107$ & $N=92$ & $N=89$ \\
\hline $\begin{array}{l}\text { Methods of environmental } \\
\text { scanning }\end{array}$ & $\%$ & $\%$ & $\%$ & $\%$ & $\%$ & $\%$ \\
\hline $\begin{array}{l}\text { Undirected viewing } \\
\text { Conditioned viewing } \\
\text { Informal search } \\
\text { Formal search }\end{array}$ & $\begin{array}{l}43,4 \\
46,9 \\
45,1 \\
48,7\end{array}$ & $\begin{array}{l}44,0 \\
51,3 \\
54,9 \\
66,3\end{array}$ & $\begin{array}{l}50,0 \\
38,9 \\
55,6 \\
44,4\end{array}$ & $\begin{array}{l}41,1 \\
50,5 \\
44,9 \\
52,3\end{array}$ & $\begin{array}{l}45,7 \\
51,1 \\
53,3 \\
66,3\end{array}$ & $\begin{array}{l}43,8 \\
49,4 \\
56,2 \\
65,2\end{array}$ \\
\hline $\begin{array}{l}\text { Application of environ- } \\
\text { mental scanning } \\
\text { Strategic appraisal }\end{array}$ & 49,6 & 65,3 & 55.6 & 47,7 & 65,2 & 68,5 \\
\hline $\begin{array}{l}\text { Assessment of opportunities } \\
\text { and threats } \\
\text { Identification of constraints } \\
\text { Planning premises and forecasts }\end{array}$ & $\begin{array}{l}56,6 \\
53,1 \\
54,9\end{array}$ & $\begin{array}{l}72,0 \\
67,4 \\
70,5\end{array}$ & $\begin{array}{l}50,0 \\
50,0 \\
44,4\end{array}$ & $\begin{array}{l}57,0 \\
53,3 \\
57,9\end{array}$ & $\begin{array}{l}69,6 \\
64,1 \\
68,5\end{array}$ & $\begin{array}{l}77,5 \\
73,0 \\
73,0\end{array}$ \\
\hline $\begin{array}{l}\text { Strategic planning } \\
\text { Strategy formulation } \\
\text { Portolio of strategic alternatives } \\
\text { Resource analysis } \\
\text { Action programmes } \\
\text { Financial evaluation } \\
\text { Lone range planning }\end{array}$ & $\begin{array}{l}54,0 \\
42,5 \\
51,3 \\
49,6 \\
51,3\end{array}$ & $\begin{array}{l}73,6 \\
52,3 \\
61,7 \\
60,1 \\
64,8\end{array}$ & $\begin{array}{l}44,4 \\
44,4 \\
44,4 \\
44,4 \\
61,1\end{array}$ & $\begin{array}{l}59,8 \\
43,0 \\
52,3 \\
51,4 \\
49,5\end{array}$ & $\begin{array}{l}68,5 \\
50,0 \\
58,7 \\
60,9 \\
62,0\end{array}$ & $\begin{array}{l}76,4 \\
55,1 \\
66,3 \\
59,6 \\
69,7\end{array}$ \\
\hline $\begin{array}{l}\text { Long range planning } \\
\text { Long range plans } \\
\text { Intermediate range plans }\end{array}$ & $\begin{array}{l}47,8 \\
54,9\end{array}$ & $\begin{array}{l}53,4 \\
67,9\end{array}$ & $\begin{array}{l}44,4 \\
44,4\end{array}$ & $\begin{array}{l}49,5 \\
57,0\end{array}$ & $\begin{array}{l}48,9 \\
68,5\end{array}$ & $\begin{array}{l}57,3 \\
68,5\end{array}$ \\
\hline $\begin{array}{l}\text { Operational planning } \\
\text { 1. Financial planning }\end{array}$ & & & & & & \\
\hline $\begin{array}{l}\text { a) An operating budget } \\
\text { b) A cash budget } \\
\text { c) A capital budget } \\
\text { 2. Tactical planning } \\
\text { 3. Operational planning } \\
\text { 4. Performance review } \\
\text { No plans formal }\end{array}$ & $\begin{array}{l}85,8 \\
84,1 \\
75,2 \\
43,4 \\
59,3 \\
86,7\end{array}$ & $\begin{array}{l}90,2 \\
90,2 \\
87,0 \\
66,8 \\
70,5 \\
88,6\end{array}$ & $\begin{array}{l}88,9 \\
88,9 \\
66,7 \\
44,4 \\
61,1 \\
83,3\end{array}$ & $\begin{array}{l}86,0 \\
84,1 \\
78,5 \\
44,9 \\
58,9 \\
87,9\end{array}$ & $\begin{array}{l}90,2 \\
88,0 \\
85,9 \\
66,3 \\
70,7 \\
88,0\end{array}$ & $\begin{array}{l}89,9 \\
92,1 \\
87,6 \\
68,5 \\
71,9 \\
88,8\end{array}$ \\
\hline $\begin{array}{l}\text { No plans formal } \\
\text { All activities } \\
\text { Detailed objectives }\end{array}$ & 7,1 & 4,7 & 5,6 & 6,5 & 6,5 & 3,4 \\
\hline $\begin{array}{l}\text { Detailed objectives } \\
\text { Participant objectives } \\
\text { Strategic objectives } \\
\text { Performance objectives } \\
\text { No formal objectives } \\
\text { Strategy formulation }\end{array}$ & $\begin{array}{l}61,9 \\
65,5 \\
70,8 \\
22,1\end{array}$ & $\begin{array}{l}64,8 \\
74,6 \\
76,2 \\
14,5\end{array}$ & $\begin{array}{l}72,2 \\
61,1 \\
72,2 \\
22,2\end{array}$ & $\begin{array}{l}57,9 \\
67,3 \\
72,0 \\
20,6\end{array}$ & $\begin{array}{l}68,5 \\
75,0 \\
75,0 \\
13,0\end{array}$ & $\begin{array}{l}64,0 \\
74,2 \\
76,4 \\
16,9\end{array}$ \\
\hline $\begin{array}{l}\text { Strategy formulation } \\
\text { Entrepreneurial mode } \\
\text { Adaptive mode } \\
\text { Planning mode } \\
\text { No modes employed }\end{array}$ & $\begin{array}{l}31,0 \\
34,5 \\
44,2 \\
11,5\end{array}$ & $\begin{array}{r}29,5 \\
39,4 \\
50,3 \\
9,8\end{array}$ & $\begin{array}{l}16,7 \\
44,4 \\
44,4 \\
16,7\end{array}$ & $\begin{array}{l}34,6 \\
32,7 \\
43,9 \\
10,3\end{array}$ & $\begin{array}{r}27,2 \\
40,2 \\
54,3 \\
7,6\end{array}$ & $\begin{array}{l}30,3 \\
39,3 \\
47,2 \\
12,4\end{array}$ \\
\hline $\begin{array}{l}\text { Application of strategy } \\
\text { Proactive strategies } \\
\text { Reactive strategies }\end{array}$ & $\begin{array}{l}83,3 \\
68,8\end{array}$ & $\begin{array}{l}94,1 \\
78,8 \\
\end{array}$ & $\begin{array}{l}80,0 \\
46,7 \\
\end{array}$ & $\begin{array}{l}85,7 \\
76,9 \\
\end{array}$ & $\begin{array}{l}94,0 \\
72,3 \\
\end{array}$ & $\begin{array}{l}93,5 \\
81,8 \\
\end{array}$ \\
\hline
\end{tabular}

